Article

\title{
An Empirical Study on the Manufacturing Firm's Strategic Choice for Sustainability in SMEs
}

\author{
Chang Juck Suh and In Tae Lee * \\ Graduate School of Business, Sogang University, 35 Baekbeom-ro, Mapo-gu, \\ Seoul 04107, Korea; cjsuh@sogang.ac.kr \\ * Correspondence: intaelee@sogang.ac.kr; Tel.: +82-70-7747-7203
}

Received: 29 January 2018; Accepted: 22 February 2018; Published: 24 February 2018

\begin{abstract}
To survive in the current competitive, unpredictable business environment, it is significant for firms to search and enforce capabilities that lead them to adapt and cope with dynamic changes of environment for their sustainability. We try to connect operation issues with sustainability in this paper. From the perspective of the dynamic capabilities of the firm, this study suggests a conceptual model that presents relationships among supply chain visibility, modular design, supply chain flexibility, and agility. We do not focus on the module buyer but on the small and middle-sized enterprises (SMEs). An empirical study is performed to verify the relationships proposed, using datasets collected from 232 manufacturing SMEs as module suppliers in South Korea. We used SPSS to analyze data and structural equation modeling to verify the hypotheses of the research model. The important contributions of this study are as follows. Firstly, we suggest relationships among supply chain visibilities and a modular design for supply chain flexibility and agility in sustainable performance. Secondly, we show that supply chain visibility directly leads firms to implement modular design in sustainable development. Thirdly, we verify the importance of supply chain visibility, not for module buyers, but for module suppliers by switching views in terms of SMEs' sustainability. Lastly, this study shows that the suppliers' modular design affects supply chain flexibility and agility, which is consistent with the findings presented in the literature.
\end{abstract}

Keywords: sustainability; SMEs; supply chain visibility; modular design; flexibility; agility

\section{Introduction}

We live in an unpredictable dynamic environment. There are some changes in business environments. Customers wants various types of products and services and product life cycles have been shortened. These changes are great risks to firms. Fast-changing markets feature both high-level competition and numerous uncertainties and operate in an unstable environment [1]. Every firm should produce new high-quality products and services at a low price for survival and sustainability. In particular, small and middle-sized enterprises (SMEs) are trying to search and enforce their core competencies and capabilities for survival. It is not a game, but a war. Changes of environment make SMEs analyze, build, and reconfigure their resources and organizational capabilities in order to achieve flexibility and agility from the perspective of sustainability. The increasing product complexity and market dynamism has forced the emergence of flexible and agile manufacturing [2]. Flexible and agile manufacturing enables a firm to survive in the competitive environment of continuous and unpredictable changes to respond quickly to customers' dynamic demands [3]. Particularly, to sustain increased competitive pressure, SMEs are continuously forced to rethink, reshape, and synchronize their existing competitive sources and capabilities [4]. Flexibility and agility are the abilities to produce various types of products shortly in a cost-effective manner. Additionally, sustainability refers to the minimization of the effect on the environment [5]. Cost-effectiveness is important to the environmental side. Therefore, the achievement of flexibility and agility are the key successful factors for sustainability. 
In this context, sustainable development has been highlighted as a central idea today [6]. For manufacturing operations, modular design is considered to be an approach that increases strategic flexibility and agility [7]. Indeed, the origin of agility, namely, the capability that includes organizational structure, information systems, and logistics processes, lies in flexible manufacturing systems [8]. The product architecture has important effects on the whole product life cycle, hence affecting sustainable characteristics of a product [9]. In terms of the ability to influence the product life cycle and sustainable characteristics, modular design has recently received great attention with regard to sustainable design [10]. Sustainable design focuses on the development of sustainable solutions, balancing private interests of the firms with environmental, economic, and social concerns [11]. The literature generally associates modular design with environmental concerns and benefits [10]. As a primary concern of sustainability, the element of cost savings has attracted increasing attention in economic sustainability [12]. Many practical advantages of modularity have been examined in recent research. Modular design has been shown to increase manufacturing efficiency and it can benefit the supply chain by reducing inventory costs and saving on lead time [13]. Therefore, obtaining flexibility and agility by modular design is a significant approach for a firm's sustainability.

In past decades, a modular supply chain environment has been emphasized in which key modules are outsourced to technically competent module suppliers [14]. SMEs as module suppliers also adapt modularity to strive to obtain flexibility and agility and cope with rapid changes and customer needs. Through communication and information sharing among supply chain partners, modular design can provide a competitive advantage [15]. A close supply chain structure facilitates information and knowledge sharing [16]. Recent modular outsourcing has resulted in differentiation with respect to firm competitiveness as firms gain dynamic capabilities through supply chain visibility. Hence, firms can reconfigure and adjust their manufacturing methods to achieve flexibility and agility. Value-added activities shift from a single organization to an overall modular supply chain when key modules are outsourced to suppliers in modular design [14].

However, there are few empirical studies to examine the relationships among supply chain visibility, suppliers' modular designs, supply chain flexibility, and agility for sustainability from the perspective of SMEs as module suppliers. Research addressing modularity focuses on the module buyer's perspective [17]. If we consider the outsourcing of modules, we must address the significance and effect of supply chain management for maintaining relationships and sharing information with partners. Particularly, this paper aims to answer the following questions:

(1) What key factors affect module suppliers' modular design when modules are outsourced from the perspective of SMEs as module suppliers?

(2) What important capabilities are necessary to establish suppliers' modular design between module buyers and suppliers for sustainability?

(3) How does supply chain visibility affect SMEs' flexibility and agility for sustainability?

Against this background, the major concern of this study is to develop a conceptual model of supply chain visibility, suppliers' modular designs, and supply chain flexibility and agility as dynamic capabilities for sustainability of SMEs from the viewpoint of the module supplier. A rigorous research model is also proposed and validated using structural equation modeling. This concept of dynamic capability helps to explain the structural relationships among the constructs concerned, providing a basis for module suppliers in SMEs' sustainability. This study makes three contributions. First, we develop and empirically validate a comprehensive model of supply chain visibility and modular design from a module supplier's perspective. Research that combined modular design with concepts from supply chain management is an emerging area [18]. However, few empirical studies address the relationship between supply chain factors and modular design as an operation issue in terms of sustainability. Secondly, we shift the viewpoint from the module buyer to the module supplier in SMEs. We focus on the module supplier's perspective to address the sustainability through obtaining supply chain flexibility and agility in SMEs, while most studies focus on the module buyer's 
perspective. Lastly, we conduct a new empirical test to provide evidence for the importance of supply chain visibility and examine the critical capabilities required to achieve flexibility and agility for sustainable competitiveness.

We organize the rest of this paper as follows: In the next session, we present a literature review on the supply chain visibility to manage modular design and the approaches to enhance supply chain flexibility and agility as a dynamic capability. We then present the research model, formulate hypotheses, and discuss the survey design. In the following section, we analyze the data, discuss the results of the study, and suggest their theoretical and managerial implications. In the final section, we discuss the study limitations and suggest topics for future study.

\section{Literature Review}

\subsection{Supply Chain Visibility}

Regarding the supply chain, management of uncertainty is the key driver to achieving supply chain performance [19]. Firms that have broader variety and higher customization find that it is difficult to predict the demand of the products [20]. There are various sources of uncertainty including demand uncertainty in the supply chain [21]. However, innovative and highly-customized product offerings force firms to obtain a sustainable competitive advantage [22]. In the sustainable supply chain, firms need to consider and address the uncertainty that surrounds environmental decisions [23]. Many researchers suggest using an approach based on cooperation between the different agents of the system to meet customer uncertainty [24]. Increasing relocation activity and the accompanying uncertainties and risks to supply chains are prompting both practitioners and academics to consider information sharing through supply chain visibility as a way in which to reduce uncertainties and risks [25]. The strategic decision-makers monitor supply chain performances. Additionally, trust and information sharing among the supply chain participants modify the supply chain performances [26]. In the context of management of uncertainty by information sharing, supply chain visibility has drawn much interest from both researchers and practitioners in supply chain management [27]. Although such visibility is a well-researched concept, a common definition is lacking. Supply chain visibility relates to the ability of sharing information on the supply chain strategy and the operations of supply chain partners [28]. Most definitions regard supply chain visibility as a type of capability or ability, although it actually involves different capabilities or abilities [29]. Pavlou and EI sawy [30] define supply chain visibility as the ability to track significant data or information on the supply chain. Rao [31] suggests that supply chain visibility is information sharing on inward-moving inventory, work-in-process, outward-bound product logistics, warehousing, and all other activities that relate to customer demand within a supply chain. Caridi et al. [28] define supply chain visibility in terms of the approach to useful information. According to definitions, visibility is the ability to share information across supply chain partners and use it in real-time.

Firms tend to use supply chain management strategies to increase their capabilities and reduce uncertainties in rapidly changing and unpredictable environments for sustainability. Supply chain management aims to maximize the synergy among supply chain partners to serve the end customer more effectively by reducing costs and adding value [32]. Firms can obtain supply chain visibility as an output of successful supply chain structures. As a result, supply chain visibility in terms of connectivity and information sharing is a key capability to implement sustainability [33]. However, most authors focus on the direct effects of supply chain visibility on firm performance [34]. Additionally, no studies have thus examined the relationships between supply chain visibility and operational issues from the supplier's perspective. In particular, module suppliers must obtain supply chain visibility in terms of networks and information sharing to cope with changing customer needs and obtain competitive advantage through a flexible manufacturing system for sustainability.

It is difficult to conceptualize supply chain visibility. Teece [35] suggests that dynamic capabilities involve the ability to sense and shape opportunities, seize opportunities, and maintain competitiveness 
by reconfiguring a firm's structure. In this way, sensing the environment, learning activities, and coordinating resources enable reconfiguration [30]. Many studies examine current supply chain management practices in terms of integration, visibility, and information sharing among supply chain participants [36]. Various studies also adopt a broader perspective of supply chain process, practices, and strategies in relation to supply chain integration, visibility, and information sharing. Firm size also influences the level of supply chain integration concerning information sharing and collaboration [37]. Speier et al. [25] investigate the relationship between information integration and the nature of relationships through a theory-based, strategy-structure-performance paradigm. Krishnamurthy [38] suggests that information sharing is a key factor in gaining supply chain visibility through supply chain velocity and viscosity. In summary, previous studies suggest that supply chain visibility is the obtainable output of supply chain integration through information sharing.

Consistent with the above studies, we defined supply chain visibility by using three constructs: visibility for sensing, visibility for learning, and visibility for coordinating through information sharing with supply chain partners.

\subsection{Modular Design}

Although the concept of modular design emerged in the 1960s, there is little consensus on a definition of modular design [15]. Prevailing definitions and concepts of modular design generally include many aspects. In the most commonly-referenced definition, Baldwin and Clark [39] define a module as a unit that has structural elements powerfully connected among themselves but weakly connected to elements in other units. Ulrich [40] defines modularity as the relationship between a product's functional and physical structures such that there is a one-to-one or many-to-one correspondence between the functional and physical structures and minimization of unintended interactions between modules. Modularity thus enables greater flexibility and agility without changing components [41]. In general, modularity refers to the degree to which a system's components can be separated and recombined [42]. Baldwin and Clark [39] regard modular design as a manufacturing strategy for effectively organizing complex products and processes. The literature suggests that modularity is a design strategy that avoids creating strong independencies among specific modules within the product [43]. Product modular design, the most concrete type of modularity, is the practice of using standardized product modules that can be easily rearranged into different functional and physical forms and shared across different product components on the production line [44]. A modular design is characterized by component commonality, component combinability, function binding, interface standardization, and loose decoupling [18]. The diversity of production is reduced and product customization is achieved by using various combinations or modifications of the modules [44]. Therefore, modularity enables a manufacturer to increase flexibility through postponement of differentiation and reduction of lead time [45].

Sustainable development has been highlighted as a significant idea [6]. The development of sustainable manufacturing is pushed by more demanding customers. Life cycle assessment is a method to assess the potential environmental impact as well as the resources used from the acquisition of raw materials to the management of waste [46]. The concept of product life cycle is related to the time from material usage, manufacturing, assembly, product use, and product recycling. Most of product life cycle costs and environmental impacts are determined during the product design stage [47]. Modular design has been suggested as a way to simplify the life cycle assessment. For the strategies, modular design has the advantages of simplifying the product design structure and increasing assembly efficiency [48]. The modifications introduced in one module influences its own life cycle, but not the entire product [49]. In terms of ability to influence the product life cycle and sustainable characteristics, modularity has gained great attention in the field of sustainable design, focusing on the developing sustainable solutions, and balancing the profit of firms against environmental, economic, and social issues [11]. Newcomb et al. [50] define the relationships between components as life cycle issues such as recycling, post-life intent, and service frequency and include them into a modular measure. Modular design 
is known as a common method to reduce a product's life cycle cost [50]. Modular design can play a significant role in the life cycle of a product in terms of ease of upgrade, maintenance, and improved efficiency [51]. Ma and Kremer [12] summarize the findings of modular design from the perspective of sustainability. Table 1 shows a summary of the literatures.

Table 1. Sustainable modular product design (MPD) literature findings.

\begin{tabular}{|c|c|c|}
\hline $\begin{array}{l}\text { Sustainability } \\
\text { Indicator }\end{array}$ & $\begin{array}{l}\text { Indication Major } \\
\text { Themes }\end{array}$ & Main Findings \\
\hline \multirow{4}{*}{ Economic } & Product innovation & $\begin{array}{l}\text { MPD affects product innovation from advantage points of marketing and } \\
\text { technology development, and both of these have positive influences on } \\
\text { product innovation. }\end{array}$ \\
\hline & Risk management & $\begin{array}{l}\text { Risk management is an application of modularity in project management } \\
\text { that primarily addresses risk reduction. }\end{array}$ \\
\hline & Profit & $\begin{array}{l}\text { MPD is positively related to profit increase without cost savings being } \\
\text { involved. }\end{array}$ \\
\hline & Cost saving & $\begin{array}{l}\text { MPD has a positive impact on both supply chain and product development } \\
\text { cost savings. }\end{array}$ \\
\hline \multirow[b]{2}{*}{ Eco-environmental } & Energy efficiency & MPD should be used to minimize energy usage rate and waste. \\
\hline & $\begin{array}{l}\text { Life cycle } \\
\text { management }\end{array}$ & $\begin{array}{l}\text { MPD can improve product life cycle performance by allocating cluster } \\
\text { components into modules from the view of the entire life cycle. }\end{array}$ \\
\hline \multirow{4}{*}{ Environmental } & Emission reduction & $\begin{array}{l}\text { MPD plays a role in green design and can be associated with multi-criteria } \\
\text { decision-making methods to satisfy the requirement of emission reduction. }\end{array}$ \\
\hline & $\begin{array}{l}\text { Natural resource } \\
\text { management }\end{array}$ & $\begin{array}{l}\text { Natural resource management emphasizes utilizing natural resources } \\
\text { efficiently and effectively by applying MPD. }\end{array}$ \\
\hline & $\begin{array}{l}\text { Environment } \\
\text { management }\end{array}$ & $\begin{array}{l}\text { Modularity and green design analysis involving optimization } \\
\text { methodologies for managing the environmental impact are sparse and } \\
\text { require further investigation. }\end{array}$ \\
\hline & $\begin{array}{l}\text { Environment } \\
\text { assessment }\end{array}$ & $\begin{array}{l}\text { MPD associated with end-of-life strategy management could help develop } \\
\text { a useful tool to assess environmental impact. }\end{array}$ \\
\hline \multirow{2}{*}{ Social-environmental } & $\begin{array}{l}\text { Client safety and } \\
\text { health }\end{array}$ & $\begin{array}{l}\text { MPD in client safety and health should focus on reliability within and } \\
\text { between modules, thus ensuring client safety. }\end{array}$ \\
\hline & $\begin{array}{l}\text { Global climate } \\
\text { change }\end{array}$ & $\begin{array}{l}\text { MPD in global climate change should focus on how to reduce pollution and } \\
\text { how to minimize the carbon footprint. }\end{array}$ \\
\hline \multirow{3}{*}{ Social } & Human diversity & $\begin{array}{l}\text { MPD affects human diversity by bringing a variety of products that fit the } \\
\text { requirements of different groups. }\end{array}$ \\
\hline & Human rights & MPD can facilitate the involvement of customers in the design stage. \\
\hline & Labor relations & $\begin{array}{l}\text { Laborers' work on the same product modules or highly related module } \\
\text { provides a good setting for team communication and responds to the need } \\
\text { for harmony. }\end{array}$ \\
\hline \multirow[b]{2}{*}{ Social-economic } & Security & Security-related MPD can be associated with product innovation. \\
\hline & Customer ethics & $\begin{array}{l}\text { MPD can affect customer ethics through customization for product features, } \\
\text { uses, or cost. }\end{array}$ \\
\hline
\end{tabular}

Sourced from [12].

Many researchers show the benefits of modular design for sustainable design according to the three main steps of the life cycle such as production, use, and disposal [10]. Additionally, modular design is a key concept in new sustainable manufacturing processes, ensuring agility, reactivity, and flexibility [10]. Modular design enables manufacturers to cope with rapidly-changing customer needs and increases the technical complexity in the production process [18]. Thus, supply chains allow the manufacturer to achieve a flexible and agile response [52]. In this context, we considered modular design as a significant factor in achieving cost-effectiveness for the environmental and economic performance of sustainability.

\subsection{Supply Chain Flexibility and Agility as a Dynamic Capability for Sustainability}

Many studies about defining various types of manufacturing flexibilities have occurred over the last three decades. However, there is no clear and common agreement on the definition of 
flexibility [53]. Zhang et al. [54] define flexibility as the organization's ability to meet an increasing variety of customer needs without excessive costs, time, or performance losses. Correa [55] also defines flexibility as an interface between the system and the external interface. Flexibility is an ability of a system to maintain its equilibrium and dynamic efficiency [56]. Flexibility is a primary tool to cope with uncertain environments.

Agility emerged as a solution to the changing economic environment and global competitiveness [56]. Ali et al. [57] define agility as the ability to manufacture and make a wide range of products with minimum cost, less time, and with high quality. Sharifi and Zhang [58] suggest that agility is concerned with the ability of an organization to cope with unexpected changes, to survive threats, and to obtain advantages from the changes by converting them into opportunities.

Many researchers show the role of human factors in supporting industrial objectives is important [59]. They address the effects of humans on the variability in the operations. Human factors are also considered a critical aspect for a successful supply chain [60]. Iravani et al. [61] suggest that in many labor-constrained systems, flexibility is mostly achieved through cross-training assignment. Garcia-Alcaraz et al. [62] show the positive impact of human resources on supply chain flexibility and agility. Also, Fruggiero et al. [63] state the effects of worker's fatigue as a human factor in manufacturing dynamics. It is important to consider the impacts of human factors on the variability of flexibility and agility.

In addition to the human factors, flexibility and agility can be both dimensions of supply chain performance [64]. A firm can achieve supply chain agility by drawing various synergies in different types of supply chain flexibility [65]. We regard supply chain flexibility and agility as different concepts in this study. Supply chain flexibility represents internally-focused manufacturers' capabilities and responsiveness in a firm's internal function such as purchasing, production, and distribution flexibility [66]. Furthermore, supply chain agility refers to externally-focused manufacturers' competencies that are related to speed at the organizational level such as rapid market responsiveness, delivery reliability, and frequency of new product introduction [67]. Supply chain flexibility is a separate and antecedent capability required for supply chain agility [68]. Supply chain agility is widely considered to be the most significant success factor in today's competitive marketplace [69]. Um et al. [66] use supply chain flexibility and agility as performance indicators for SC reaction and responsiveness in managing a variety of issues.

Corporate sustainability has been focused on the triple bottom line incorporating equity, environment, and economics [70]. Supply chain flexibility is one strategy which has been famous in achieving agility and high responsiveness of supply chains [71]. However, there are few studies that investigate the impact of flexibility on supply chain designs and consequent operation activities on environmental performance [72]. One challenge in becoming more sustainable is to create flexibility in exploiting and controlling resources in the choice of alternative strategic actions. Flexibility reduces risk and uncertainty [73] and contributes to the sustainability of the firm [74]. Although strategic flexibility is considered to be necessary to respond to environmental changes and the increasing demand to satisfy economic needs, it is still unclear how this dynamic capability alters sustainability performance [75]. Firms are forced to redesign their operational processes and implement a flexible system of structures and processes in order to effectively and efficiently cope with changing customer needs and increasing demand for sustainable offers [76]. Nidumolu et al. [75] suggest that operational innovations are important for creating a sustainable value. Obtaining flexibility in various sides needs to be present in product development, manufacturing, and supply chain activities to increase responsiveness for sustainability performance [77]. Additionally, agility needs to be coupled with sustainability. Supply chain agility enables firms to react quickly and more effectively to market volatility and uncertainties, thereby allowing the firm to obtain a superior competitive advantage, such as obtaining market sensitivities, synchronizing supply with demand, and achieving shorter cycle time [64]. On the other hand, sustainability refers to the minimization of the impact to the environment and increasing the rate of recycled materials. The integration of these three offers the business benefits, 
such as improved product variety with minimal environmental impact [3]. Since it is possible for strategic flexibility to build, integrate, and reconfigure operational capabilities, supply chain flexibility can achieve sustainability performance [78].

This differentiation of a firm's internal and external activities confirms the dynamic capabilities theory [35], which concerns the ability to integrate, build, and reconfigure internal and external competencies to address rapidly-changing environments. Dynamic capabilities allow firms to maintain a competitive advantage [66]. Many researchers suggest that dynamic capabilities are antecedent to organizational and strategic routines and new value-creating strategies [79]. Zollo and Winter [80] propose that dynamic capability is a stable pattern of collective activity that can be learned and through which firms can systematically generate and modify their operating routines to enhance effectiveness. The dynamic capabilities view is an extension of the resource-based view (RBV) to dynamic markets [81]. Teece [35] proposes a framework for dynamic capabilities that includes the categories of "sense opportunities", "seize opportunities", and "maintain competitiveness". Although dynamic capabilities have been widely adopted since the introduction of the concept, most studies of them are conceptual and empirical studies are few [81].

Thus, the provision of a dynamic capability, such as rapid response in a supply chain has great potential in a dynamic environment. On the basis of this viewpoint, supply chain flexibility and agility is regarded as a dynamic capability in this study.

\section{Research Model and Hypotheses}

Several different sources of uncertainty have been recognized in supply chain management [21]. To manage uncertainty and dynamism in the business environment, firms seek extensive, superior-quality information [82]. Recent studies of supply chain management have addressed information sharing and supply chain visibility based on the assumption that greater information sharing increases a firm's ability to respond quickly to environmental changes for sustainability. In this context, dynamic capabilities are significant for organizational reconfiguration. Dynamic capabilities are directed towards strategic change and aligning the organization with the environment [83]. They can be disaggregated conceptually into a firm's capabilities as follows: sensing opportunities, seizing opportunities, and redeploying their resources [35].

In this context, we regard flexibility and agility through supply chain visibility as a dynamic capability that includes visibility for sensing opportunities, visibility for learning to seize opportunities, and visibility for coordinating to redeploy management resources. In addition, flexibility and agility are essential to organizational reallocation and structural reconfiguration. In terms of supply chain integration as a dynamic capability, an integrated network of internal and external partners provides the organizational capability to respond to changing environments [84]. In the initial stage, automobile manufacturers (module buyers) such as Hyundai Motors began to outsource modules to their supply chain partner for cost reduction. They cultivated a parent subsidiary model with their subcontractors that produced modules. As a result, they could obtain an outsourcing effect such as cost efficiencies through the modularization of production consignment types. Today, the higher the labor cost, the lower the effect of cost reduction. On the contrary, many automobile manufacturers rely heavily on their suppliers of components and systems. In this situation, they pursue a modularization of cooperation-type strategy where role assignment is possible, which then increases the importance of the SME's role as a module supplier. Automobile manufacturers establish the line-up plan of the model and produce modules to meet the automobile manufacturer's needs. Through this cooperation, it is possible for module suppliers to focus on their professional role for sustainability. From the module supplier's perspective, it is so important to obtain flexibility and agility as a dynamic capability in order to achieve performance of sustainability. Figure 1 illustrates the conceptual process for this study.

Modular design significantly influences a manufacturer's channel management and production planning techniques [44]. Additionally, it enables the manufacturer to reconfigure the supply chain design related to the structures of production and logistics networks, processes, and relationships 
among supply chain partners for integration [52]. A manufacturer is able to schedule and control production and supply chain processes effectively [18]. This integration increases the visibility of supply chains. In particular, a manufacturer must maintain close interactions and relationships with suppliers to decide interface specifications to ensure the combinability of modules [52]. Modular design also enhances the ability of the manufacturer to collaborate with suppliers on new product development [85]. From the perspective of SMEs as module suppliers, it is so important to obtain supply chain visibility through information sharing with their buyer. Thus module suppliers can improve their modular design and enhance their flexibility and agility by obtaining supply chain visibility for sustainability. We just focused on the perspective of SMEs as module suppliers for their sustainability in this study. Figure 2 shows the research model in this study.

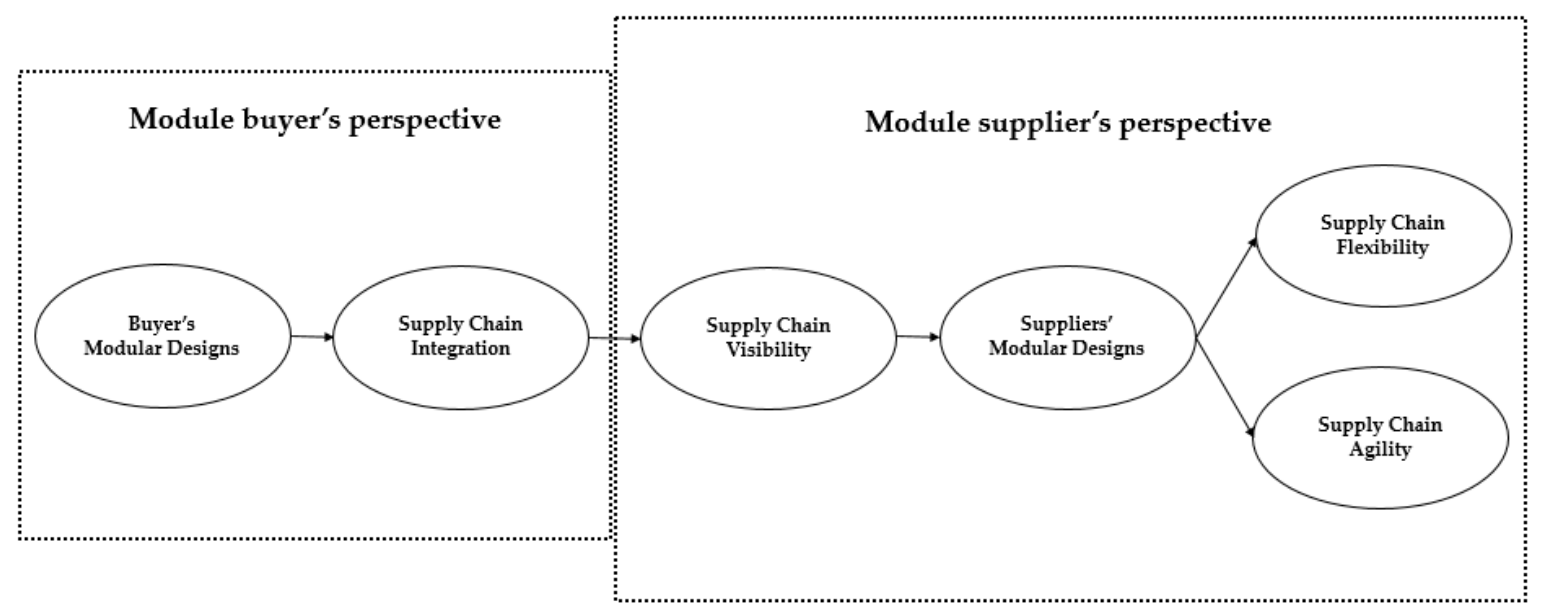

Figure 1. Framework for module buyer and supplier's perspective.

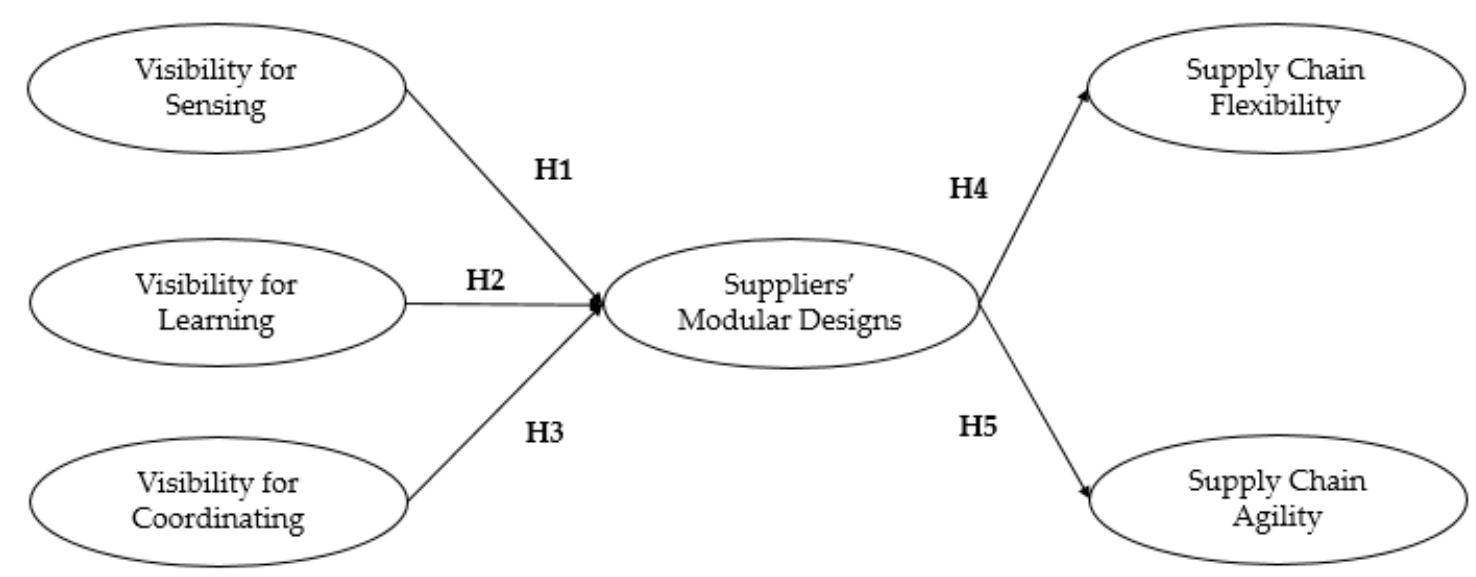

Figure 2. Research model from the perspective of module suppliers in SMEs.

\subsection{Visibility for Sensing and Modular Design}

Supply chain visibility is effective in a sustainable supply chain [86]. Market orientation as a firm strategy helps the firm to achieve sustainable values creation [87]. This makes firms decide how to allocate resources to create capabilities and how sets of capabilities should be coordinated and organized for sustainable performances [88]. Manufacturing firms should consider modular design in supply chain design [89]. Sako [90] argues that modular design is essential for product, process, and supply chain design. Additionally, modular design usually requires the integration of designers, producers, and customers. Modular design can play an important role in the life cycle of a product [51]. Information sharing with partners is a key organizational process in supply chains. A product with 
high modularity implies that modules can be outsourced to suppliers [91]. As product modules are outsourced to external partners in the supply chain, information sharing is important to manufacture modular products.

To design modular product interfaces accurately, it is necessary to predict and obtain information on changes in the market and customer needs [92]. The information on market and customer needs offered by supply chain participants can facilitate the rapid reorganization of supply chain structure and the manufacturing system [93]. Information on market and customer needs influences the range and degree of module suppliers' modular designs. Therefore, the visibility for sensing market and customer needs influences module suppliers' modularity. Based on the above discussion, we suggest the following hypothesis that links visibility for sensing and suppliers' modular designs.

Hypothesis 1 (H1). Obtaining visibility for sensing is positively related to the module suppliers' modular designs.

\subsection{Visibility for Learning and Modular Design}

Hult et al. [94] suggest that visibility for learning is a strategic corporate resource. Studies have shown that learning is an important determinant of an organization's capability to implement innovative practices, new processes, and new technologies [95]. Okhuysen and Eisenhardt [96] examine how learning facilitates the improvement of a manufacturing process and the development of a flexible process. In this way, the learning process enables firms to utilize and recognize their resources. Zollo and Winter [80] define dynamic capabilities as learned and stable patterns of collective activities. Organizations systematically generate and modify operational routines to improve effectiveness. As organizational routines accumulate experience, knowledge is articulated through collective discussions and codified through the creation of written manuals. Learning is a critical factor for innovations and performance. Schroeder et al. [97] show a positive relationship between both internal and external learning and organizational performance using resource-based hypotheses.

Firms that collaborate closely with supply chain participants on a regular basis promote extensive interactions with their upstream and downstream partners, which provides a basis for sharing tacit knowledge [98]. Firms are able to create new knowledge from the existing knowledge shared by supply chain partners. Close relationships with supply chain members can also transform knowledge into explicit knowledge. In this process, firms may conceptualize information about customer needs and supply chain structure in terms of product and process design. The acquisition and propagation of knowledge significantly influence supply chain partners and enhance strategic behaviors [99]. For example, regular intellectual interchange with partners transforms an ambiguous relationship to a casual one and provides a basis for fundamental change [80]. Consequently, learning by supply chain participants facilitates change in manufacturing systems and processes that can respond rapidly to trends in the external environment for sustainability from the perspective of the module supplier. Therefore, we hypothesize the following:

Hypothesis 2 (H2). Obtaining visibility for learning is positively related to the module suppliers' modular designs.

\subsection{Visibility for Coordinating and Modular Design}

Studies suggest that coordinating organizational activities, or sharing information to make business decisions and designing business systems across the supply chain, is important for supply chain integration [100]. Developing joint systems and sharing information among supply chain members encourage the sharing of risks and resources across the supply chain [101]. Many studies have shown that manufacturers coordinate their supply chain structures strategically and organizationally when adopting modular design [102]. Sabel and Zeitlin [103] suggest that manufacturers tend to approximate other manufacturers' internal business processes to find solutions to technical and marketing problems when adopting a modular system. In addition, Sanchez and Mahoney [104] 
propose that if modular products are outsourced to supply chain partners, they are loosely integrated into relationships. However, these are the perspectives of module buyers or module product manufacturers as users.

However, Jacobs et al. [15] show that modularity facilitates supplier, manufacturing, and design integration by sharing communication and information among supply chain partners. Indeed, the supply chain should be integrated as closely as possible to ensure the conformity of different product components [105]. Hence, from the perspective of module suppliers of SMEs, it is so important to share information regarding coordination with their buyer for advancing suppliers' modularity. We have shown these processes in Figure 1. Therefore, we hypothesize the following:

Hypothesis 3 (H3). Obtaining visibility for coordinating is positively related to the module suppliers' modular designs.

\subsection{Modular Design and Supply Chain Flexibility and Agility}

Correa [55] suggests two major drivers of flexibility: environmental uncertainties and products and process variability. The uncertain changes within the system and outside the system require flexibility to deal with them. When it is required to offer a variety of products by carrying out different processes, the flexibility is essential [44]. Modular design allows a firm to control the extent to which changes in processes or requirements affect the product and provide it with the flexibility and agility to meet these changing processes. The concept of product life cycle is related to the time from material usage, manufacturing assembly, product use, and product recycling. Modular design is a way to life cycle assessment. In terms of the ability to influence the product life cycle and sustainable characteristics, modular design has been the focus attention in the field of sustainable design as a sustainable solution [11]. Modular design allows firms to increase their capability for production process reconfiguration and allows a more effective use of the production capacity [106]. Modular design provides various types of strategic flexibility and product variety [41]. Modular design is positively related to profit increase with cost reduction in terms of economic performance of sustainability. Jacobs et al. [15] suggest that modular design allows firms to have flexibility and agility for manufacturing and allows firms to respond rapidly to changes in the market and in their customers. Additionally, modular design enhances human diversity by bringing a variety of products that fit the requirements of different groups. Modular designs have been found to be central to increasing product variety [107]. In addition, modular design can reduce the impact of uncertain demand forecasts [84]. As above, modular design has a positive impact on flexibility in a variety of ways. Modular design enables firms to quickly respond to market changes, thus allowing an efficient planning and control of the environmental impact of the production phase [108].

Agility is a dynamic strategy that depends on a firm's ability to quickly translate customer needs into new products and services in order to satisfy an individual's specific requirements [39]. Flexibility and agility can reduce uncertainty and risk, contributing to the sustainability of firms. In consideration of sustainability, operational efficiency and time reduction are also important performance metrics. Modular design enables firms to achieve short delivery times and increase product features and quality [44]. Modular design is the best way in which to achieve variety and shorten variety and speed, thereby reducing delivery time [18]. Even Ulrich [40] suggests that modularity can increase product variety and shorten delivery lead time. When firms decrease the set-up and switching time by using modular design, they can produce mixed flexibility [7]. Lorenzi and Lello [109] contend that modular design can reduce cycle time. Supply chain agility enables firms to react quickly and more effectively to market dynamics and uncertainties, thereby allowing the firm to obtain a superior competitive advantage for sustainability [64]. Therefore, one of the benefits of modular design is operational efficiency by reducing response time and delivery time. According to Howard and Squire [110], the direct effect of modular design is a decrease in delivery lead times through better flexibility. As above, modular design has a positive impact on supply chain flexibility 
and agility in the creation of sustainable value. Through obtaining supply chain flexibility and agility, firms can achieve sustainability performance. Therefore, we hypothesize the following:

Hypothesis 4 (H4). Suppliers' modular designs are positively related to supply chain flexibility.

Hypothesis 5 (H5). Suppliers' modular designs are positively related to supply chain agility.

\section{Research Design and Methodology}

This study investigates (1) the relationship among supply chain visibility, suppliers' modular designs, supply chain flexibility, and agility, (2) the influence of supply chain visibility on modular design for supply chain flexibility and agility in achieving sustainability, and (3) the impact of modular design on supply chain flexibility and agility in the relationships between operation issues and SMEs' sustainability. We draw the conceptual model and synthesize the research model based on the literature review to reflect dynamic capability perspective. The primary research instrument for this study is a rigorously-validated questionnaire.

\subsection{Focus Group Interview}

We modelled the framework from the perspective of dynamic capability. This framework was developed from the main findings in the literature concerning the relationships between supply chain visibility and modular design and the influence of modular design on flexibility and agility. We conducted a preliminary focus group interview to confirm this framework. We used a focus group that included five university professors and operations or supply chain experts from five module suppliers to understand the practices. This focus group also confirmed the relationship among the variables and discussed the model's usability. We posed interview questions from the module supplier's perspective. For example, "What is the most important factor for collaboration and coordination with a module buyer?" "What are the factors to be addressed in advance of manufacturing modular design?" and "What is the meaning of visibility in your supply chain?". We estimated the significance of information sharing with the module buyer from the module supplier's perspective. Additionally, we detected that it is critical for the module supplier to obtain supply chain visibility, although not as critical to share information from the module buyer's perspective. These two groups of practitioners have different opinions because of their situations and functions. We composed the survey questionnaire on the basis of the findings of previous studies. Then, after we selected the items to be measured, we discussed their items with the focus group members. Before the survey, we eliminated ambiguous or inaccurate items from the interview.

\subsection{Measurement Items}

We adopted measurement items from relevant studies and adapted them to our specific context. The survey contained 23 items representing six constructs. The constructs were supply chain visibility [93], modular design $[7,44]$, supply chain flexibility, $[64,66]$ and supply chain agility $[64,66]$. The preliminary survey was reviewed by five senior-level managers in manufacturing or supply chain management for ambiguity, readability, and clarity. Four academic researchers reviewed the survey for item representativeness, item specificity, and contents validity. Some items were eliminated and rewritten based on feedback from practitioners and researchers. The resulting model used 21 survey items, and each construct had three or four items after some items were eliminated from the initial factor analysis because of low factor loading values. All items were measured on a 7 Likert-type scale.

The constructs of interest in this study were measured by using multiple items. Supply chain visibility included three constructs: visibility for sensing, visibility for leaning, and visibility for coordinating. We defined these constructs by assuming that visibility for sensing represents the ability to which a firm can acquire real-time external information and quickly recognize changes in the environment [93]. External information includes external sensed events, supply chain change, 
market intelligence about customer needs, market trends, and so on. Visibility for learning represents the ability to which a firm can extend its knowledge base from supply chain relationships and explore the external sources of knowledge to improve flexibility and agility [111]. Visibility for coordinating represents the ability to which a firm can share comprehensive information to support supply chain decision-making. For these visibility measures, respondents rated the three constructs used by Wei and Wang [93]. The measures for visibility were based on scales that rated their ability to share information with the module buyer.

We define modular design as the practice of using standardized modules that can be easily reassembled or rearranged into different functional forms and shared across product lines. For modular design measures, respondents rated the four items used by Worren et al. [7] and Tu et al. [44]. The measures of modular design were based on "extent of use" scales (i.e., the degree to which certain initiatives are used in the firm).

We define supply chain flexibility as the capability to be internally focused on a firm's functions such as adaptability of changes, and agility as the capability to be externally focused on a firm's functions such as speed at the business level [66]. For flexibility and agility measures, respondents rated three or four items by Um [66]. All measurement items are shown in Table 2.

Table 2. Construct items and their sources.

\begin{tabular}{|c|c|c|}
\hline \multicolumn{2}{|r|}{ Item Constructs } & Loadings \\
\hline \multicolumn{3}{|c|}{$\begin{array}{l}\text { Visibility for sensing [93] } \\
\text { (Cronbach's } \alpha=0.895)\end{array}$} \\
\hline VFS1 & Our firm shares information on upcoming product-related changes with the buyer & 0.858 \\
\hline VFS2 & Our firm shares information on changes of customer needs with the buyer & 0.822 \\
\hline VFS3 & Our firm shares information on market trends and forecasts with the buyer & 0.896 \\
\hline VFS4 * & Our firm shares information on promotion and marketing plans with the buyer & \\
\hline \multicolumn{3}{|c|}{$\begin{array}{l}\text { Visibility for learning [93] } \\
\text { (Cronbach's } \alpha=0.912)\end{array}$} \\
\hline VFL1 & \multirow{3}{*}{$\begin{array}{l}\text { Different points of view are discussed in regular meetings with the buyer } \\
\text { New insights are developed through the joint decision-making process with the buyer } \\
\text { Our firm exchanges valuable knowledge and information for improvement with the } \\
\text { buyer }\end{array}$} & 0.896 \\
\hline VFL2 & & 0.868 \\
\hline VFL3 & & 0.880 \\
\hline \multicolumn{3}{|c|}{$\begin{array}{l}\text { Visibility for coordinating [93] } \\
\text { (Cronbach's } \alpha=0.927)\end{array}$} \\
\hline VFC1 & Our firm exchanges information on order forecasting with the buyer & 0.921 \\
\hline VFC2 & Our firm exchanges information on production schedules with the buyer & 0.916 \\
\hline VFC3 & Our firm exchanges information on payment processing with the buyer & 0.848 \\
\hline VFC4 & Our firm exchanges information on customer preference or needs with the buyer & 0.804 \\
\hline \multicolumn{3}{|c|}{$\begin{array}{l}\text { Suppliers' modular designs }[7,44] \\
\text { (Cronbach's } \alpha=0.922)\end{array}$} \\
\hline SMD1 & Our products use a more advanced modular design, compared to the competitors & 0.838 \\
\hline SMD2 & Our products share a high number of common modules, compared to the competitors & 0.828 \\
\hline SMD3 & Our product modules can be easily added to a standard base unit & 0.875 \\
\hline SMD4 & $\begin{array}{l}\text { Our product modules can be effectively reassembled and rearranged to suit the } \\
\text { customer's needs }\end{array}$ & 0.843 \\
\hline \multicolumn{3}{|c|}{$\begin{array}{l}\text { Supply chain flexibility }[64,66] \\
\text { (Cronbach's } \alpha=0.852 \text { ) }\end{array}$} \\
\hline SCF1 & Our firm can change quantity of the customer's orders & 0.702 \\
\hline SCF2 & Our firm can change delivery times of orders placed with the customer & 0.778 \\
\hline SCF3 & Our firm can change the production volume & 0.874 \\
\hline $\mathrm{SCF} 4 *$ & Our firm can change the delivery schedules to meet changing customer requirements & \\
\hline \multicolumn{3}{|c|}{$\begin{array}{l}\text { Supply chain agility }[54,66] \\
\text { (Cronbach's } \alpha=0.907)\end{array}$} \\
\hline SCA1 & Our firm can rapidly reduce product development cycle time & 0.854 \\
\hline SCA2 & Our firm can rapidly reduce manufacturing lead time & 0.901 \\
\hline SCA3 & Our firm can rapidly improve delivery reliability & 0.828 \\
\hline SCA4 & Our firm can rapidly improve responsiveness to changing market needs & 0.799 \\
\hline
\end{tabular}

* Deleted from the final model due to the low loadings. 


\subsection{Sampling Procedure and Data Description}

We extracted samples of industries used in previous research on modularity. For example, Lau et al. [112] investigate product modularity and product performance in the electronics, toys, and plastics industries. Tu et al. [44] verify the relationship among product modularity, process modularity, dynamic teaming, and mass customization capability in the automobile, fabricated metal, electronics, electrical equipment, furniture, appliances, industrial machine, and transportation equipment industries. Duray et al. [102] analyze modularity issues in the furniture, fabricated metal products, machinery, electronic equipment, transportation equipment, and instrument industries. Thus, we selected samples from industries that already adopt modular design.

A survey was used to collect the data and test the 5 hypotheses. Respondents from multiple industries, functions, and organizational levels were included in the sampling frame to ensure the generalizability of the results. We obtained a list of the top 100 manufacturers in South Korea and contacted their supply chain partners through manufacturers. Samples included 2186 SMEs across electronics (19.8\%), automobile (15.9\%), electronic components/computer (13.8\%), construction (12.5\%), metal fabrication $(10.3 \%)$, shipbuilding $(9.1 \%)$, machinery $(8.2 \%)$, furniture $(5.2 \%)$, others $(5.2 \%)$. These SMEs all use modular design in their production process. Our target respondents consisted of experienced manufacturing or supply chain management who deal with the manufacturing system structure, supply chain, and customer on a regular basis. These managers represented certain departments, namely manufacturing $(46.1 \%)$, supply chain management $(27.9 \%)$, R and D $(13.8 \%)$, and management $(12.1 \%)$.

To avoid selection bias, we also compared our sample demographics with the sample frame to ensure the representativeness of our respondents. We found that the sample industries were widely distributed. The majority of respondents were highly experienced managers above the junior manager level. Hence, our survey respondents reflect the target sample frame and population studied, which limits the potential for selection bias [113]. Table 3 shows the respondents' demographic characteristics.

Table 3. Demographic characteristics.

\begin{tabular}{|c|c|c|}
\hline & Frequency & Percentage $(\%)$ \\
\hline \multicolumn{3}{|l|}{ Size (No. of personnel employed) } \\
\hline Small-sized ( $<250$ employees) & 164 & $70.7 \%$ \\
\hline Medium-sized (between 250 and 500 employees) & 68 & $29.3 \%$ \\
\hline Total & 232 & $100 \%$ \\
\hline \multicolumn{3}{|l|}{ Total annual sales (US Dollars in Millions) } \\
\hline$<10$ & 16 & $6.9 \%$ \\
\hline $10-49.9$ & 97 & $41.8 \%$ \\
\hline $50-99.9$ & 78 & $33.6 \%$ \\
\hline $100-150$ & 41 & $17.7 \%$ \\
\hline Total & 232 & $100 \%$ \\
\hline \multicolumn{3}{|l|}{ Industrial sector } \\
\hline Electronics & 46 & $19.8 \%$ \\
\hline Automobile & 37 & $15.9 \%$ \\
\hline Electronic components/computer & 32 & $13.8 \%$ \\
\hline Construction & 29 & $12.5 \%$ \\
\hline Metal fabrication & 24 & $10.3 \%$ \\
\hline Shipbuilding & 21 & $9.1 \%$ \\
\hline Machinery & 19 & $8.2 \%$ \\
\hline Furniture & 12 & $5.2 \%$ \\
\hline Others & 12 & $5.2 \%$ \\
\hline Total & 232 & $100 \%$ \\
\hline \multicolumn{3}{|l|}{ Respondent profile (Position) } \\
\hline Jr. Manager & 42 & $18.1 \%$ \\
\hline Sr. Manager & 49 & $21.1 \%$ \\
\hline Director & 97 & $41.8 \%$ \\
\hline Executive & 44 & $19.0 \%$ \\
\hline Total & 232 & $100 \%$ \\
\hline
\end{tabular}


The survey was pre-tested with 32 qualified respondents from the sample frame, using mail. We conducted a principal factor analysis and reliability analysis with data from the pre-test, which determined that the items were loaded correctly on their respective constructs and all measures were reliable with Cronbach's $\alpha$ values over 0.70. A total of 247 respondents were pre-qualified and 232 completed surveys were received (i.e., 15 surveys with missing values were eliminated), leaving an effective response rate of $11.3 \%$. Data from these 232 surveys were used in the subsequent analysis.

\subsection{Scale Purification and Construct Validation}

Scale purification was conducted using a reliability test and confirmatory factor analysis (CFA). Cronbach's $\alpha$ values were used to assess the scale reliability of each construct. The reliability of all factors are reported in Table 2. The Cronbach's $\alpha$ values of every item were greater than 0.7 , which were acceptable statistical results [114].

Through the CFA, those items that showed low item-to-scale total correlations and those that did not load significantly on the appropriate construct were eliminated (Table 2). Convergent validity was assessed by using the factor loadings of each measurement. All factor loadings were positive and greater than 0.5 , and the critical ratio for each loading was significant $(p>0.05)$, indicating convergent validity [115]. The composite reliabilities and average variance extracted (AVE) values were calculated by using the procedures of Fornell and Larcker [116]. The composite reliability values for all constructs exceeded 0.7 and all AVE values exceeded 0.5 , indicating significant convergent validity (Table 4 ).

Table 4. Convergent validity.

\begin{tabular}{|c|c|c|c|c|c|}
\hline Construct & Mean & Std. Dev & AVE * & CR $* *$ & Range of Factor Loading \\
\hline 1. Visibility for sensing & 4.49 & 1.336 & 0.738 & 0.894 & $0.822-0.896$ \\
\hline 2. Visibility for learning & 4.29 & 1.428 & 0.881 & 0.949 & $0.868-0.896$ \\
\hline 3. Visibility for coordinating & 4.66 & 1.507 & 0.763 & 0.927 & $0.804-0.921$ \\
\hline 4. Suppliers' modular designs & 4.92 & 1.287 & 0.716 & 0.910 & $0.828-0.875$ \\
\hline 5. Supply chain flexibility & 4.52 & 1.439 & 0.881 & 0.939 & $0.702-0.874$ \\
\hline 6. Supply chain agility & 4.64 & 1.409 & 0.716 & 0.909 & $0.799-0.901$ \\
\hline
\end{tabular}

* AVE: Average variance extracted, ${ }^{* *} \mathrm{CR}$ : Composite reliability.

We also assessed discriminant validity, which indicates the degree to which the measures of different constructs are unique [117]. When measuring different constructs, correlations must be low to sufficient discriminant validity, which occurs if items share common variance more with their respective constructs than with other constructs [116]. In this study, discriminant validity was supported because the AVE for each of the constructs was higher than the squared correlation between that construct and each of the other constructs (Table 5).

Table 5. Discriminant validity.

\begin{tabular}{lcccccc}
\hline Construct & VFS & VFL & VFC & SMD & SCF & SCA \\
\hline 1. Visibility for sensing & 0.738 & & & & & \\
2. Visibility for learning & 0.525 & 0.881 & & & & \\
3. Visibility for coordinating & 0.410 & 0.562 & 0.763 & & & \\
4. Suppliers' modular designs & 0.249 & 0.281 & 0.243 & 0.716 & & \\
5. Supply chain flexibility & 0.216 & 0.272 & 0.149 & 0.344 & 0.881 & \\
6. Supply chain agility & 0.234 & 0.285 & 0.184 & 0.388 & 0.421 & 0.716 \\
\hline
\end{tabular}

* All correlations are significant at the 0.001 level. ${ }^{* *}$ AVE values are on the diagonal; squared correlations are of-diagonal.

\subsection{Common Method Assessment}

The items used in this study were part of a large-scale questionnaire. Therefore, it is important that respondents would have been able to deduce the objective of this study to force their answers to be consistent. To minimize the effects of common method variance, I examined this issue by using Harman's single factor analysis. The examination of the un-rotated factor structure involving 26 items 
revealed distinct factors that paralleled ours, each with eigenvalues greater than one, which collectively accounted for $66.7 \%$ of the variance explained. The results showed that no general factor was apparent, with factor 1 accounting for only $18.4 \%$ of the variance, while the other factors accounted for an additional $48.3 \%$. The result reduces the concern about common method variance.

\subsection{Results for Hypotheses Test}

We used CFA (confirmatory factor analysis) and structural equation modelling (SEM) to test our research model by using SPSS 18.0 and AMOS 18.0. We used a two-step approach to analyze the data [115]. The final structural equation model with standardized regression weights, shown in Figure 3, had the following fit values: $\mathrm{CMIN} / \mathrm{DF}=1.612, \mathrm{GFI}=0.918, \mathrm{IFI}=0.980, \mathrm{NFI}=0.949, \mathrm{CFI}=0.980$, RMSEA $=0.045$.

Table 6 provides the results of path analysis for the theoretical links among supply chain visibility, modular design, supply chain flexibility, and agility.

Table 6. Path analysis results.

\begin{tabular}{cccccc}
\hline & Hypothesis & Estimate & Std. Estimate & Std. Error & Critical Ratio \\
\hline H1 & Visibility for sensing $\rightarrow$ Modular design & $0.203^{* * *}$ & $0.232^{* * *}$ & 0.076 & 2.679 \\
H2 & Visibility for learning $\rightarrow$ Modular design & $0.261^{* * *}$ & $0.295^{* * *}$ & 0.092 & 2.842 \\
H3 & Visibility for coordinating $\rightarrow$ Modular design & $0.130^{*}$ & $0.152^{*}$ & 0.075 & 1.736 \\
H4 & Modular design $\rightarrow$ Supply chain flexibility & $0.645^{* * *}$ & $0.653^{* * *}$ & 0.069 & 9.395 \\
H5 & Modular design $\rightarrow$ Supply chain agility & $0.721^{* * *}$ & $0.645^{* * *}$ & 0.068 & 10.673 \\
\hline
\end{tabular}

* Significant at $0.05, * * *$ significant at 0.001 .

According to the empirical results, all hypotheses were significantly supported. Hypothesis 1 , which addressed that visibility for sensing directly leads to suppliers' modular designs, was accepted. More specifically, the path coefficient was $0.232(p<0.001)$. This indicates that information sharing with market and customers is positively and significantly associated with suppliers' modular designs. $\mathrm{H} 2$ indicates that visibility for learning leads to suppliers' modular designs. These results suggest that sharing of learning information with their buyer is positively and significantly associated with suppliers' modular designs $(0.295, p<0.001)$.

As posited in $\mathrm{H} 3$, the empirical results show that visibility for coordinating directly leads to suppliers' modular designs $(0.152, p<0.05)$, suggesting that information sharing of coordinating with module buyer is positively and significantly associated with suppliers' modular designs.

$\mathrm{H} 4(0.653, p<0.001)$ and $\mathrm{H} 5(0.645, p<0.001)$ are regarding the effects of modular design on supply chain flexibility and agility. Many researchers suggest that modular design is the best way in which to improve flexibility and agility in flexible manufacturing systems. It is so important for SMEs to obtain flexibility and agility through modular design to cope with dynamic changes of business environments. Figure 3 shows the SEM model, together with their path coefficients and significance levels.

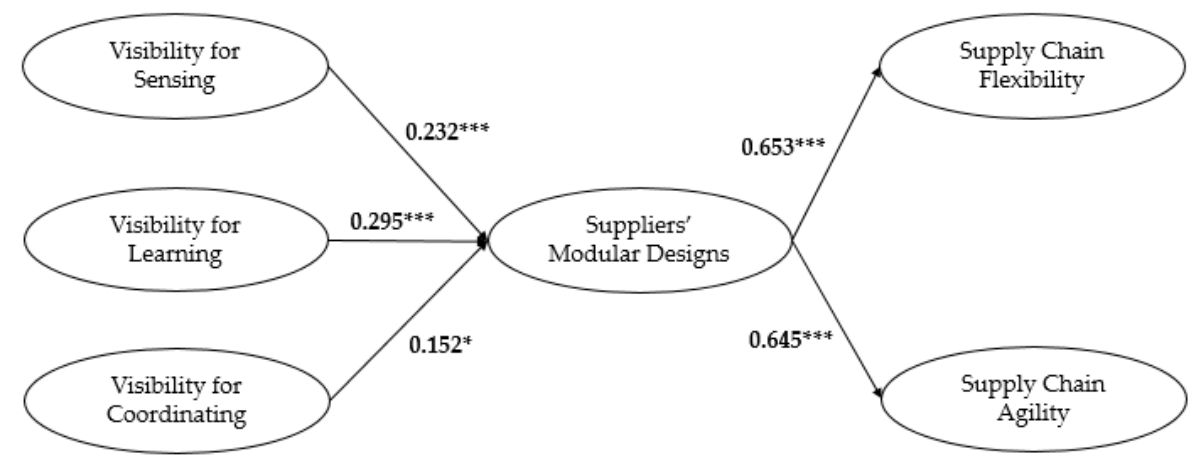

Figure 3. Path analysis results. ${ }^{*}$ Significant at $0.05,{ }^{* *}$ significant at $0.01,{ }^{* * *}$ significant at 0.001 . 


\section{Discussion and Conclusions}

The SEM results verify the relationship hierarchy of the research model, illustrating that supply chain visibility leads to achieving supply chain flexibility and agility (i.e., the dynamic capability for sustainability) through increased suppliers' modular designs (i.e., the manufacturing method for sustainability). The results support the notion that supply chain visibility is an important antecedent to suppliers' modular designs. This means that information sharing with module buyers is significant to suppliers' modular designs from the perspective of SMEs as module suppliers. In addition, suppliers' modular designs influence both supply chain flexibility and agility. Thus, supply chain visibility improves suppliers' modular designs, and supports obtaining supply chain flexibility and agility as supply chain performance for sustainability.

In this study, supply chain visibility is considered to manage uncertainty for sustainability. It is important to collaborate with the different agents of the supply chain to meet customer uncertainty [24]. To manage uncertainty and dynamism in the business environment, firms seek extensive, superior quality information [82]. Both practitioners and academics should consider information sharing through supply chain visibility as a way in which to reduce uncertainties and risks [25]. Supply chain visibility consists of visibility for sensing, visibility for learning, and visibility for coordinating in terms of information sharing. It includes sensing opportunities, seizing opportunities, and maintaining competitiveness. Supply chain visibility is a key capability to implement sustainability [118]. If they can rapidly sense market or customer changes, firms can create and advance their modular designs as a flexible strategy. Hence, they can flexibly cope with change in their external environments. Oksuysen and Eisenhardt [96] show the process through learning facilitating the manufacturing process. Firms are able to create new knowledge by sharing existing knowledge. In this learning process, knowledge-sharing enhances firms' abilities to develop and improve their modular design as sustainable development. Outsourcing of modules allows assigning roles to the module buyer and supplier. Module buyers establish the line-up plan of the product and focus on the development of the assembly process, while module suppliers design and produce modules to meet the module buyer's needs. Under a cooperation type strategy, it is thus possible to focus on individualized roles. In this process, visibility for coordinating enforces their modular design from the module supplier's perspective in SMEs' sustainability.

We suggest that modular design is able to enforce supply chain flexibility and agility in this study. Many researchers show the benefits of modular design for sustainable design according to the three main steps of the life cycle, such as production, use and disposal [10]. Modula design is suitable for sustainable development. There are various benefits of modular design for sustainable design in terms of the life cycle. It is possible to gain agility, reactivity, and flexibility [10]. Modular design is known as a common method to reduce the product's life cycle cost [50]. Modular design can play a significant role in the life cycle of a product in terms of ease of upgrade, maintenance, and improved efficiency [51]. Additionally, it is possible for firms to cope with the rapidly-changing dynamic environment and technical complexity of their sustainability. Modular designs in the supply chain are competencies that form the basis of the value-creating strategy [108]. Therefore, it is necessary to consider modular design in sustainable supply chain design.

This study shows that supply chain flexibility and agility are multi-item constructs used to represent internal capability about operating level responsiveness in variability and external capability about the inter-firm levels of responsiveness in speed. These dynamic capabilities are able to lead to competitive advantages from the perspective sustainability. Internal capability includes ability to change the quantities of customers' orders, delivery time of orders, and product volume. Additionally, external capability includes the ability to reduce the product development cycle time and manufacturing lead time, reduce the response time to changing needs, and to improve delivery reliability. Today, it is becoming more sustainable to create flexibility in exploiting and controlling resources in the choice of alternative strategic actions [74]. Obtaining flexibility on various sides needs to be present in product development, manufacturing, and supply chain activities to increase 
responsiveness for sustainability performance [77]. Thereby, it is so important to obtain supply chain flexibility and agility in order to achieve sustainability performance.

In a rapidly changing competitive environment, managers find ways in which to reinvent value and reinforce capabilities for sustainability. Every firm is trying to search and enforce strategic capabilities to reduce risk by managing uncertainty and to cope with dynamic changes in the business environment [24]. For production strategies from the perspective of SMEs as module suppliers, we suggest a framework of organizational capabilities and operation issues with sustainability. Supply chain visibility can allow firms to reconfigure their supply chains and strategic value. In particular, when module components are outsourced to their suppliers, it is essential to obtain supply chain visibility between module buyer and supplier. Supply chain visibility is a key capability to implement sustainability in terms of connectivity and information sharing [33]. We focus on the strategic sustainability of SMEs and empirically show these relationships among supply chain visibility, modular design, supply chain flexibility, and agility from the perspective of module suppliers' sustainability.

The important contributions of this study are as follows. Firstly, it suggests relationships among supply chain visibilities and modular design for supply chain flexibility and agility as dynamic capabilities in sustainable performance. We also verify the effects of supply chain visibility on suppliers' modular designs, supply chain flexibility, and agility from the perspective of the module supplier. It is important to understand how firms can achieve a flexible manufacturing system to enforce a continuous competitiveness for survival and sustainability. In this context, this study theoretically and empirically identifies three organizational capabilities (visibility for sensing, visibility for learning, and visibility for coordinating) that affect modular design, supply chain flexibility, and agility from the dynamic capability view.

Secondly, we suggest that supply chain visibility will directly lead firms to implement modular design in sustainable development. We find that it is significant to obtaining supply chain visibility and it enables firms to modularize through information sharing of sensing, learning, and coordinating with module buyers. Dubey et al. [118] investigate the impact of bundling resources to build supply chain visibility and its influences on supply chain sustainability performance. Practically, managers should consider including their upstream suppliers and downstream customers when designing supply chain structures and objectives, particularly because they are related to modular design. A firm's capabilities and information sharing may impact supply chain sustainability [119]. This would allow firms to reinforce their capabilities and implement modular designs in module suppliers for sustainability.

Thirdly, we suggest the importance of supply chain visibility, not for module buyers, but for module suppliers, by switching the view in terms of SMEs' sustainability. While some researchers suggest that product structure coordinates supply chain interaction as a strategy and that modular design loosely coupled and decentralized the supply chain structure [120], others state that supply chain integration influences modular design and performance [121] from the perspective of the module buyer. However, from this perspective of module suppliers as SMEs, information sharing through supply chain visibility enhances and improves their modular design for supply chain flexibility and agility for sustainability. Upstreaming supply chain visibility is, in terms of connectivity and information sharing, a key capability to implement sustainability [118]. Although many studies examine modular designs from a module buyer's perspective, there are few insights from module suppliers' perspective as SMEs. As outsourcing of modules has been growing recently, it is necessary to cultivate a system of specialization and cooperation between module buyers and suppliers through information sharing. Such a system would enable them to concentrate on their core competencies. Module buyers are not limited to the development of existing modules and can concentrate on new technological R and D. Furthermore, module suppliers can focus on creating advanced modules by suggesting directions for module development to module buyers in order to accelerate modular designs for flexibility and agility. In particular, module suppliers must obtain supply chain visibility to reinforce sustainable competitive advantages. This shows that the relationships enable having small production runs with multiple product varieties which match individual needs. It seeks to promote 
collaboration in place of specialization such that SMEs will lead to sustainability in manufacturing and effectively competing in the market.

Finally, this study shows that suppliers' modular designs directly affect their flexibility and agility, which is consistent with the findings presented in the literature. Ma and Kremer [12] find that modular design has a positive impact on sustainability with analysis of a literature review. Given the demand to reduce uncertainty in the business environment, modular designs are effective methods for obtaining flexibility and agility for sustainability. Additionally, modular design is a key concept in sustainable manufacturing processes, ensuring agility, reactivity, and flexibility [10]. When integrating sustainability in studies, all dimensions of sustainability would guide modular design, including not only economic views but also environmental and social aspects [12]. They can allow a firm to cope with unpredictable customer needs and to reduce uncertainty, thereby leading to cost reductions as well as higher operational efficiency and customer service in terms of sustainability.

From a practical perspective, this study provides insights into how managers should create strategic sustainable value from supply chain visibility from a module supplier's perspective. Module buyers must also obtain supply chain visibility by enforcing their core competencies. Managers should also share information on their market and customers with supply chain partners to better understand customer expectations. Indeed, they should aim to create a joint decision-making process for modules with their partners. In addition, managers should be flexible and adaptable to cope with changeable environments. Many firms focus on improving information coordination, but this is only one part of the overall supply chain visibility. Managers should quickly respond to and flexibly cope with changes in market uncertainties. Flexibility and agility are able to achieve sustainability performance, because it is possible of strategic flexibility and agility to build, integrate, and reconfigure operational capabilities [78]. For managers that intend to outsource modules, our findings suggest that they should develop the flexibility and agility to challenge dynamic markets for sustainability by deploying modularity-enhancing resources through closer cooperation with their supply chain partners.

\section{Limitations and Future Research}

This study is subject to several limitations that should be addressed in future research. Firstly, we used data from respondents, each of whom provided information on all measures. This may cause common method bias, although we selected respondents who were pre-qualified and had experience with related tasks. Future research should thus incorporate data from multiple respondents on each measure to validate levels in our findings. Secondly, this study investigated only one dimension of modular design and flexibility. Modularity and flexibility have various levels and dimensions. The results could change according to the degree and dimension of modularity and flexibility. In future research, I hope to study the ways in which the degree of modularity influences different types of flexibility and agility or firm performances.

Acknowledgments: The authors would like to thank the editors and anonymous reviewers for their constructive comments and helpful suggestions.

Author Contributions: In Tae Lee designed the research framework, analyzed the data and wrote the paper. Chang Juck Suh guided this work and provided extensive revisions during the study.

Conflicts of Interest: The authors declare no conflict of interest.

\section{References}

1. Moon, K.K.L.; Mo, P.L.L.; Chan, R.L.Y. Enterprise risk management; In-sights form a textile-apparel supply chain. Int. J. Risk Conting. Manag. 2014, 3, 18-30. [CrossRef]

2. Tanimizu, Y.; Sakaguchi, T.; Iwamura, K.; Sugimura, N. Evolutional reactive scheduling for agile manufacturing systems. Int. J. Prod. Res. 2006, 44, 3727-3742. [CrossRef] 
3. Vinodh, S.; Sundaraj, G.; Deyadasan, S.R.; Rajanayagam, D. TADS-ABC: A system for costing total agile design systems. Int. J. Prod. Res. 2009, 47, 6941-6966. [CrossRef]

4. Ali, Z.; Sun, H.; Ali, M. The impact of managerial and adaptive capabilities to stimulate organizational innovation in SMEs: A complementary PLS-SEM approach. Sustainability 2017, 9, 2157. [CrossRef]

5. Vinodh, S. Improvement of agility and sustainability: A case study in an India rotary switches manufacturing organization. J. Clean. Prod. 2010, 18, 1015-1020. [CrossRef]

6. Sachs, J.D. The Age of Sustainable Development; Columbia University Press: New York, NY, USA, 2014.

7. Worren, N.; Moore, K.; Cardona, P. Modularity, strategic flexibility, and firm performance: A study of the home appliance industry. Strateg. Manag. J. 2002, 23, 1123-1140. [CrossRef]

8. Aitken, J.; Christopher, M.; Towill, D. Understanding implementing and exploiting agility and leanness. Int. J. Logist. Res. Appl. 2002, 5, 59-74. [CrossRef]

9. Bonvoisin, J.; Halstenberg, F.; Buchert, T.; Stark, R. A systematic literature review on modular product design. J. Eng. Des. 2016, 27, 488-514. [CrossRef]

10. Sonego, M.; Echeveste, M.E.S.; Debarba, H.G. The role of modularity in sustainable design: A systematic review. J. Clean. Prod. 2018, 176, 196-209. [CrossRef]

11. Skelos, S.J. Promoting effectiveness in sustainable design. Proc. CIRP 2015, 29, 13-18. [CrossRef]

12. Ma, J.; Kremer, G.E.O. A systematic literature review of modular product design (MPD) from the perspective of sustainability. Int. J. Adv. Manuf. Technol. 2016, 86, 1509-1539. [CrossRef]

13. Okudan, G.E.; Lin, T.K.; Chiu, M.C. Carbon footprint implications of modularity and projections for the reverse logistics. In Proceedings of the International Workshop on Green Supply Chain, Arras, France, 21-22 June 2012.

14. Doran, D.; Hill, A.; Hwang, K.; Jacobs, G. Supply chain modularization: Cases from the French automobile industry. Int. J. Prod. Econ. 2007, 106, 2-11. [CrossRef]

15. Jacobs, M.A.; Droge, C.; Vickery, S.K.; Calantone, R. The effects of product modularity on competitive performance: Do integration strategies mediate the relationship? Int. J. Oper. Prod. Manag. 2007, 27, 1046-1068. [CrossRef]

16. Diez, J.R. Innovative networks in manufacturing: Some empirical evidence from the metropolitan area of Barcelona. Technovation 2000, 20, 139-150. [CrossRef]

17. Gershenson, J.K.; Prasas, G.J.; Zhang, Y. Product modularity: Definitions and benefits. J. Eng. Des. 2003, 14, 295-313. [CrossRef]

18. Salvador, F.; Forza, C.; Rungtusanatham, M. Modularity, product variety, production volume, and component sourcing: Theorizing beyond generic prescriptions. J. Oper. Manag. 2002, 20, 549-575. [CrossRef]

19. Petrovic, D. Simulation of supply chain behavior and performance in an uncertain environment. Int. J. Prod. Econ. 2001, 71, 429-438. [CrossRef]

20. Lo, S.M.; Power, D. An empirical investigation of the relationship between product nature and supply chain strategy. Supply Chain Manag. Int. J. 2010, 15, 139-153. [CrossRef]

21. Ho, C.F.; Tai, Y.M.; Tai, Y.M.; Chi, Y.P. A structural approach to measuring uncertainty in supply chains. Int. J. Electron. Commer. 2005, 9, 91-114.

22. Calantone, R.J.; Harmancioglu, N.; Droge, C. Inconclusive innovation "returns": A meta-analysis of research on innovation in new product development. J. Prod. Innov. Manag. 2010, 27, 1065-1081. [CrossRef]

23. Song, M.L.; Fisher, R.; Wang, J.L.; Cui, L.B. Environmental performance evaluation with big data: Theories and methods. Ann. Oper. Res. 2016, 1-14. [CrossRef]

24. Fera, M.; Fruggiero, F.; Lambiase, A.; Macchiaroli, R.; Miranda, S. The role of uncertainty in supply chains under dynamic modeling. Int. J. Ind. Eng. Comput. 2017, 8, 119-140. [CrossRef]

25. Speier, C.; Mollenkopf, D.; Stank, P.S. The role of information integration on facilitating 21st century supply chains: A theory-based perspective. Transp. J. 2008, 47, 21-38.

26. Bowersox, D.J.; Calantone, R.J. Global logistics. J. Int. Mark. 1998, 6, 83-93.

27. Yu, M.C.; Goh, M. A multi-objective approach to supply chain visibility and risk. Eur. J. Oper. Res. 2014, 233, 125-130. [CrossRef]

28. Caridi, M.; Crippa, L.; Perego, A.; Sianesi, A.; Tumino, A. The benefits of supply chain visibility: A value assessment model. Int. J. Prod. Econ. 2014, 161, 1-19. [CrossRef] 
29. Goh, M.; De Souze, R.; Zhang, A.N.; He, W.; Tan, P.S. Supply chin visibility: A decision making perspective. In Proceedings of the 4th IEEE Conference on Industrial Electronics and Applications, Xi'an, China, 25-27 May 2009; pp. 2546-2551.

30. Pavlou, P.A.; EI Sawy, O.A. From IT leveraging competence to competitive advantage in turbulent environments: The case of new product development. Inf. Syst. Res. 2006, 17, 198-227. [CrossRef]

31. Rao, S. Supply chain management: Strengthening the weakest link. In Team Leader for Industrial Automation; Frost \& Sullivan: San Antonio, TX, USA, 2004.

32. Pires, S.R.; Bremer, C.F.; De Santa Eulalia, L.A.; Goulart, C.P. Supply chain and virtual enterprises: Comparisons, migration and a case study. Int. J. Logist. Res. Appl. 2001, 4, 297-311. [CrossRef]

33. Dubey, R.; Gunasekaran, A. Exploring the relationship between leadership, operational practices, institutional pressures an environmental performance: A framework for green supply chain. Int. J. Prod. Econ. 2015, 160, 120-132. [CrossRef]

34. Pidun, T.; Felde, C. Two cases on how to improve the visibility of business process performance. In Proceedings of the 45th Hawaii International Conference on System Sciences, Maui, HI, USA, 4-7 January 2012.

35. Teece, D.J. Explicating dynamic capabilities: The nature and micro-foundations of sustainable enterprise performance. Strateg. Manag. J. 2007, 28, 1319-1350. [CrossRef]

36. Pearcy, D.H.; Giunipero, L.C. Using e-procurement applications to achieve integration: What role does firm size play? Int. J. Supply Chain Manag. 2008, 13, 26-34. [CrossRef]

37. Johnson, P.F.; Klassen, R.D.; Leenders, M.R.; Awaysheh, A. Selection of planned supply initiatives: The role of senior management expertise chain. Int. J. Oper. Manag. 2007, 27, 1280-1302. [CrossRef]

38. Krishnamurthy, S. Supply Chain Intelligence: White Paper; WIPRO Tech.: Bengaluru, India, 2002.

39. Baldwin, C.Y.; Clark, K.B. Design Rules: The Power of Modularity; MIT Press: Cambridge, MA, USA, 2000.

40. Ulrich, K.T. The role of product architecture in the manufacturing firm. Res. Policy 1995, 24, 419-440. [CrossRef]

41. Sanchez, R. Modular architecture, knowledge assets and organizational learning: New management processes for product creation. Int. J. Technol. Manag. 2000, 19, 610-629. [CrossRef]

42. Schilling, M.A. Toward a general modular systems theory and its application to interfirm product modularity. Acad. Manag. Rev. 2000, 25, 312-334. [CrossRef]

43. Bask, M.; Lipponern, M.; Tinnila, M. The concept of modularity diffusion from manufacturing service production. J. Manuf. Techol. 2010, 21, 355-375. [CrossRef]

44. Tu, Q.; Vonderembse, M.A.; Ragu-Nathan, T.S.; Ragu-Nathan, B. Measuring modularity-based manufacturing practices and their impact on mass customization capability: A customer-driven perspective. Decis. Sci. 2004, 35, 147-168. [CrossRef]

45. Yeung, J.H.Y.; Selen, W.; Zhou, M. Postponement strategy from a supply chain perspective: Cases from China. Int. J. Phys. Distrib. Logist. Manag. 2007, 37, 331-356. [CrossRef]

46. ISO 14044. Environmental Management_Life Cycle Assessment_Requirement and Guidelines; ISO: Geneva, Switzerland, 2006.

47. Dowlatshahi, S. A modeling approach to logistics in concurrent engineering. Eur. J. Oper. Res. 1999, 115, 59-76. [CrossRef]

48. Yan, J.; Feng, C.; Kai, C. Sustainability-oriented product modular design using kernel-based fuzzy c-means clustering and genetic algorithm. J. Eng. Manuf. 2012, 226, 1635-1647. [CrossRef]

49. Recchioni, M.; Mandorli, F.; Germani, M.; Faraldi, P.; Polverini, D. Life-cycle assessment simplification for modular products. Advances in Life Cycle Engineering for Sustainable Manufacturing Businesses. In Proceedings of the 14th CIRP Conference on Life Cycle Engineering, Tokyo, Japan, 11-13 June 2007; pp. 53-58. [CrossRef]

50. Newcomb, P.J.; Bras, B.; Rose, D.W. Implications of modularity on product design for the life cycle. J. Mech. Des. 1998, 120, 483-490. [CrossRef]

51. Mutingi, M.; Dube, P.; Mbohwa, C. A modular product design approach for sustainable manufacturing in a fuzzy environment. Proc. Manuf. 2017, 8, 471-478. [CrossRef]

52. Peng, D.X.; Liu, G.; Heim, G.R. Impacts of information technology on mass customization capability of manufacturing plants. Int. J. Oper. Prod. Manag. 2011, 31, 1022-1047. [CrossRef]

53. Kumar, D.; Chen, W.; Simpson, T.W. A market driven approach to product family design. Int. J. Prod. Res. 2009, 47, 71-104. [CrossRef] 
54. Zhang, M.; Guo, H.; Huo, B.; Zhao, X.; Huang, J. Linking supply chain quality integration with mass customization and product modularity. Int. J. Prod. Econ. 2017. [CrossRef]

55. Correa, H.L. Linking Flexibility, Uncertainty and Variability in Manufacturing Systems; Avebury: London, UK, 1994.

56. Jahanzaib, M.; Massod, S.A.; Akhtar, K.; Ali, K. Managing competitiveness using production volumes: Product variety model for automobile industry. Life Sci. J. 2013, 10, 202-208.

57. Ali, A.; Jahanzaib, M.; Aziz, H. Manufacturing flexibility and agility: A distinctive comparison. Nucleus 2014, 51, 379-384.

58. Sharifi, H.; Zhang, Z. A methodology for achieving agility in manufacturing organizations: An introduction. Int. J. Prod. Econ. 1999, 62, 7-22. [CrossRef]

59. Yee, R.W.Y.; Yeung, A.C.L.; Cheng, T.C.E. The impact of employee satisfaction on quality and profitability in high-contact service industries. J. Oper. Manag. 2008, 26, 651-668. [CrossRef]

60. Lengnick-Hall, M.L.; Lengnick-Hall, C.A.; Rigsbee, C.M. Strategic human resource management and supply chain orientation. Hum. Res. Manag. Rev. 2013, 23, 366-377. [CrossRef]

61. Iravani, S.M.; Van Oyen, M.P.; Sims, K.T. Structural flexibility: A new perspective on the design of manufacturing and service operations. Manag. Sci. 2005, 51, 151-166. [CrossRef]

62. Garicia-Alcaraz, J.L.; Maldonado-Macias, A.A.; Hernandez-Arellano, J.L.; Blanco-Fernandez, J.; Jimenez-Macias, E.; Saenz-Diez Muro, J.C. The impact of human resources on the agility, flexibility and performance of wine supply chains. Agric. Econ. 2017, 63. [CrossRef]

63. Fruggiero, F.; Riemma, S.; Ouazene, Y.; Macchiarili, R.; Guglielmi, V. Incorporating the human factor within manufacturing dynamics. IFAC-PapersOnLine. 2016, 49, 1691-1696. [CrossRef]

64. Swafford, P.M.; Ghosh, S.; Murthy, N. The antecedents of supply chain agility of a firm: Scale development and model testing. J. Oper. Manag. 2006, 24, 170-188. [CrossRef]

65. Agarwal, A.R.S.; Tiwari, M.K. Modeling the metrics of lean, agile and leagile supply chain: An ANP-based approach. Eur. J. Oper. Res. 2006, 173, 211-225. [CrossRef]

66. Um, J.; Lyons, A.; Lam, H.K.; Cheng, T.C.E.; Dominguez-Pery, C. Product variety management and supply chain performance: A capability perspective on their relationships and competitiveness implications. Int. J. Prod. Econ. 2017, 187, 15-26. [CrossRef]

67. Swafford, P.M.; Ghosh, S.; Murthy, N. Achieving supply chain agility through IT integration and flexibility. Int. J. Prod. Econ. 2008, 116, 288-297. [CrossRef]

68. Bernardes, E.S.; Hanna, M.D. A theoretical review of flexibility, agility and responsiveness in the operations management literature toward a conceptual definition of customer responsiveness. Int. J. Oper. Prod. Manag. 2009, 29, 30-53. [CrossRef]

69. Goldman, S.L.; Nagel, R.N.; Preiss, K. Agile Competitors and Virtual Organizations: Strategic for Enriching the Customer; Van Nostrand Reinhold: New York, NY, USA, 1995.

70. Anderson, D.R. The critical importance of sustainability risk management. Risk Manag. 2006, 53, 66-74.

71. Siddiqui, F.; Haleem, A.; Wadhwa, S. Role of supply chain management in context of total quality management in flexible systems: A state of the art literature review. Glob. J. Flex. Syst. Manag. 2009. [CrossRef]

72. Shukla, A.C.; Deshmukh, S.G.; Kanda, A. Environmentally responsive supply chains: Learning form Indian auto sector. J. Adv. Manag. Res. 2009, 6, 154-171. [CrossRef]

73. Ramirez, A.M.; Morales, V.J.G.; Aranda, D.A. Knowledge creation flexibility of distribution of information. Ind. Manag. Data Syst. 2012, 112, 166-185. [CrossRef]

74. Sushil, S. Strategic flexibility: The evolving paradigm of strategic management. Glob. J. Flex. Syst. Manag. 2015, 16, 113-114. [CrossRef]

75. Nidumolu, R.; Prahald, C.K.; Rangaswami, M.R. Why sustainability is now the key driver of innovation. IEEE Eng. Manag. Rev. 2015, 43, 85-91. [CrossRef]

76. Kollk, A.; Pinske, J. Business response to climate change: Identifying emergent strategies. Calif. Manag. Rev. 2005, 47, 6-20. [CrossRef]

77. Gelhard, C.; Delft, S. The role of strategic and value chain flexibility in achieving sustainability performance: An empirical analysis using conventional and consistent PLS. In Proceedings of the 2nd International Symposium on Partial Least Squares Path Modeling, Seville, Spain, 16-19 June 2015.

78. Kortmann, S.; Gelhard, C.; Zimmermann, C.; Piller, F.T. Linking strategic flexibility and operational efficiency: The mediating role of ambidextrous operational capabilities. J. Oper. Manag. 2014, 32, 475-490. [CrossRef] 
79. Grant, R. Prospering in dynamically-competitive environments: Organizational capability as knowledge integration. Organ. Sci. 1996, 7, 375-387. [CrossRef]

80. Zollo, M.; Winter, S.G. Deliberate learning and the evolution of dynamic capabilities. Organ. Sci. 2002, 13, 339-351. [CrossRef]

81. Wu, L.Y. Applicability of the resource-based and dynamic-capability view under environmental volatility. J. Bus. Res. 2010, 63, 27-31. [CrossRef]

82. Daft, R.L.; Lengel, R.H. Organizational information requirements media richness and structural design. Manag. Sci. 1986, 32, 554-571. [CrossRef]

83. Zahra, S.A.; George, G. Absorptive capacity: A review, reconceptualization, and extension. Acad. Manag. Rev. 2002, 28, 185-203. [CrossRef]

84. Vickery, S.K.; Koufteros, X.; Droge, C. Does product platform strategy mediate the effects of supply chain integration on performance? IEEE Trans. Eng. Manag. 2013, 60, 750-762. [CrossRef]

85. Zhang, J.M.; Xu, J.; Tang, B. Introduction of Modular Design in the Conceptual Design of Refrigerators. In Applied Mechanics and Materials; Trans Tech Publications: Zurich, Switzerland, 2014; pp. 96-99.

86. Boyd, B.K.; Haynes, K.T.; Hitt, M.A.; Bergh, D.D.; Ketchen, D.J. Contingency hypotheses in strategic management research use, disuse, or misuse? J. Manag. 2012, 38, 278-313. [CrossRef]

87. Taghian, M. Marketing planning: Operationalising the market orientation strategy. J. Mark. Manag. 2010, 26, 825-841. [CrossRef]

88. Stank, T.P.; Davis, B.R.; Fugate, B.S. A strategic framework for supply chain oriented logistics. J. Bus. Logist. 2005, 26, 69-73. [CrossRef]

89. Parker, G.G., Jr.; Anderson, E.G. Supply Chain Integration: Putting Humpty-Dumpty Back Together Again; AMACOM: New York: NY, USA, 2002.

90. Sako, M. Modularity and Outsourcing: The Nature of Co-Evolution of Product Architecture and Organization Architecture in the Global Automotive Industry; Oxford University Press: New York, NY, USA, 2003.

91. Novak, S.; Eppinger, S.D. Sourcing by design: Product complexity and the supply chain. Manag. Sci. 2001, 47, 189-204. [CrossRef]

92. Du, X.; Jiao, J.; Tseng, M.M. Architecture of product family: Fundamentals and methodology. Concurr. Eng. Res. Appl. 2001, 19, 309-325. [CrossRef]

93. Wei, H.L.; Wang, E.T.G. The strategic values of supply chain visibility: Increasing the ability to reconfigure. Eur. J. Inf. Syst. 2010, 19, 238-249. [CrossRef]

94. Hult, G.T.M.; Ketchen, D.J.; Nichols, E.L. Organizational learning as a strategic resource in supply chain management. J. Oper. Manag. 2003, 21, 541-556. [CrossRef]

95. Tu, Q.; Vonderembse, M.A.; Ragu-Nathan, T.S.; Sharkey, T.W. Absorptive capacity: Enhancing the assimilation of time-based manufacturing practices. J. Oper. Manag. 2006, 24, 692-710. [CrossRef]

96. Okhuysen, G.A.; Eisnehardt, K.M. Integrating knowledge in groups: How formal interventions enable flexibility. Organ. Sci. 2002, 13, 370-386. [CrossRef]

97. Schroeder, R.G.; Bates, K.A.; Junttila, M.A. A resource-based view of manufacturing strategy and the relationships to manufacturing performance. Strateg. Manag. J. 2002, 23, 105-117. [CrossRef]

98. Linderman, K.; Schroeder, R.G.; Zheer, S.; Liedtke, C.; Choo, A.S. Integrating quality management practices with knowledge creation processes. J. Oper. Manag. 2004, 22, 589-607. [CrossRef]

99. Yang, J.R.; Liu, Q.Y. Design method research on green modular that oriented remanufacturing engineering. Appl. Mech. Mater. 2013, 365-366, 545-548. [CrossRef]

100. Lee, H.L. Creating value through supply chain integration. Supply Chain Manag. Rev. 2000, 30-36. [CrossRef]

101. Mentzer, J.T. Supply Chain Management; Sage: Thousand Oaks, CA, USA, 2000.

102. Duray, R.; Ward, P.T.; Milligan, G.W.; Bery, W.L. Approached to mass customization: Configurations and empirical validation. J. Oper. Manag. 2000, 18, 605-625. [CrossRef]

103. Sabel, C.F.; Zetlin, Z. Neither modularity nor relational contracting: Inter-firm collaboration in the new economy. Enterp. Soc. 2004, 5, 388-403. [CrossRef]

104. Sanchez, R.; Mahoney, J.T. Modularity, flexibility, and knowledge management in product and organization design. Strateg. Manag. 1996, 17, 63-76. [CrossRef]

105. Dube, P.; Muyengwa, G.; Battle, K. The Impact of Product Modularization on Supply Chain Relationships: A Furniture Industry Perspective; Southern African Institute of Industrial Engineering: Johannesburg, South Africa, 2013. 
106. Swaminanthan, J.M.; Tayur, S.R. Models for supply chains in E business. Manag. Sci. 2003, 49, 1387-1406. [CrossRef]

107. Patel, P.C.; Jayaram, J. The antecedents and consequences of product variety in new ventures: An empirical study. J. Oper. Manag. 2014, 32, 34-50. [CrossRef]

108. Aoki, K.; Staeblein, T.; Tomino, T. Monozukuri Capability to address product variety: A comparison between Japanese and German automotive makers. Int. J. Prod. Econ. 2014, 147, 373-384. [CrossRef]

109. Lorenzi, S.; Lello, A.D. Product modularity theory and practice: The benefits and difficulties in implementation within a company. Int. J. Automot. Techol. Manag. 2001, 1, 425-448. [CrossRef]

110. Howard, M.; Squire, B. Modularization and the impact on supply chain relationships. Int. J. Oper. Prod. Manag. 2007, 26, 714-729. [CrossRef]

111. Johnson, J.L.; Sohi, R.S. The role of relational knowledge stores in interfirm partnering. J. Mar. Res. 2004, 68, 21-36. [CrossRef]

112. Lau, A.K.W.; Yam, R.C.M.; Tang, E.P.Y. Supply chain integration and product modularity: An empirical study of product performance for selected Hong Kong manufacturing industries. Int. J. Oper. Prod. Manag. 2010, 30, 20-56. [CrossRef]

113. Mentzer, J.T.; Flint, D.J. Validity in logistics research. J. Bus. Logist. 1997, 18, 199-216.

114. Johnson, R.A.; Wichern, D.W. Applied Multivariate Statistical Analysis; Prentice-Hall: New York, NY, USA, 1998.

115. Gerbing, D.W.; Anderson, J.C. An updated paradigm for scale development incorporating unidimensionality and its assessment. J. Mar. Res. 1988, 25, 186-192. [CrossRef]

116. Fornell, C.; Larcker, D.F. Evaluating structural equation models with unobservable variables and measurement error. J. Mar. Res. 1981, 18, 39-50. [CrossRef]

117. Stratman, J.K.; Roth, A.V. Enterprise resource planning (ERP) competence constructs: Two-stage multi-item scale development and validation. Decis. Sci. 2002, 33, 601-628. [CrossRef]

118. Dubey, R.; Gunasekaran, A.; Childe, S.; Papadopoulos, T.; Luo, Z.; Roubaud, D. Upstream supply chain visibility and complexity effect on focal company's sustainable performance: Indian manufacturers' perspective. Ann. Oper. Res. 2017. [CrossRef]

119. Eckstein, D.; Goellner, M.; Blome, C.; Henke, M. The performance impact of supply chain agility and supply chain adaptability: The modeling effect of product complexity. Int. J. Prod. Res. 2015, 53, 3028-3046. [CrossRef]

120. Galvin, P.; Morkel, A. The effect of product modularity on industry structure: The case of the world bicycle industry. Ind. Innov. 2001, 8, 31-47. [CrossRef]

121. Lau, A.K.W.; Yam, R.C.M.; Tang, E.P.Y. Supply chain product co-development, product modularity and product performance: Empirical evidence form Hong Kong manufacturers. Ind. Manag. Data Syst. 2007, 107, 1036-1065. [CrossRef]

(c) 2018 by the authors. Licensee MDPI, Basel, Switzerland. This article is an open access article distributed under the terms and conditions of the Creative Commons Attribution (CC BY) license (http://creativecommons.org/licenses/by/4.0/). 